\title{
INFLUENCE OF PLASMA SPRAYING CONDITIONS ON THE MICROSTRUCTURE AND FUNCTIONAL PROPERTIES OF WC-Cr-Ni METALOCERAMIC LAYERS
}

\author{
WPEYW WARUNKÓW NATRYSKIWANIA PLAZMOWEGO \\ NA MIKROSTRUKTURE I W I AŚCIWOŚCI UŻYTKOWE WARSTW \\ METALOCERAMICZNYCH TYPU WC-Cr-Ni
}

\begin{abstract}
The article presents the results of research on the impact of the conditions of plasma spraying on thickness and porosity, as well as the erosion resistance of $W C-C r-N i$ metaloceramic coatings. It was shown that the selection of current intensity - $450 \mathrm{~A}$ and flow rate $\mathrm{H}_{2}=5 \mathrm{dm}^{3} / \mathrm{min}$ and $\mathrm{Ar}=68 \mathrm{dm}^{3} / \mathrm{min}$ allows obtaining a coating with a thickness of approx. $177 \mu \mathrm{m}$ and low porosity $<6 \%$. At the same time, this coating is characterised by the greatest hardness - 758 HVO.5, and the best erosion resistance at room and elevated temperature. The analysis of test results indicates that lower current and hydrogen content in the plasma stream do not ensure sufficient melting of the metallic matrix of the powder - Ni and $\mathrm{Cr}$, and thus greater brittleness of the coating and its lower erosion resistance. It was also found that an increase in plasma stream energy due to an increase in torch current or hydrogen flow rate may cause tungsten carbide to decompose in the plasma stream - the phase affecting hardness and abrasion resistance.
\end{abstract}

Keyroords: plasma spraying, metaloceramic coatings, carbide coatings
W artykule przedstawiono wyniki badań wptywu warunków natryskiwania plazmowego na grubość i porowatość, a także odporność erozyjna powtok metaloceramicznych typu $\mathrm{WC}-\mathrm{Cr}-\mathrm{Ni}$. Wykazano, że dobór natężenia pradu - 450 A oraz natężenia przeptyrou $\mathrm{H}_{2}=5 \mathrm{dm}^{3} /$ min i $\mathrm{Ar}=68 \mathrm{dm}^{3} / \mathrm{min}$, umożliwia uzyskanie powtoki o grubości ok. $177 \mu$ m i matej porowatości $<6 \%$. Jednocześnie powtoka ta charakteryzuje się największa twardościa - 758 HVo.5, i najlepsza odpornościa erozyjna w temperaturze pokojowej oraz podwyższonej. Analiza wyników badań wskazuje, że mniejsze natężenie pradu $i$ zawartość wodoru w strumieniu plazmy nie zapewnia wystarczajacego stopienia metalicznej osnowy proszku - Ni i Cr, a przez to większa kruchościa powtoki i jej mniejsza odpornościa erozyjna. Ustalono również, że zwiększenie energii strumienia plazmy na skutek wzrostu natężenia pradu palnika lub natężenia przeptywu wodoru może powodować rozktad weglika wolframu w strumieniu plazmy -fazy decydujacej o twardości i odporności na ścieranie.

Stowa kluczowe: natryskiwanie plazmowe, powtoki metaloceramiczne, poretoki weglikowe

\section{INTRODUCTION}

Thermal spraying processes are one of the basic coating technologies that increase the durability of machinery and equipment. Increased resistance to erosive and corrosive wear is possible through the use of metaloceramic coatings containing carbide particles, including $\mathrm{WC}$ and $\mathrm{CrC}$, in metallic matrix - most often $\mathrm{Co}, \mathrm{Ni}$ and $\mathrm{Cr}$. Metaloceramic coatings are produced primarily in the process of high velocity spraying HVOF (High Velocity Oxygen Fuel) [1, 2]. Recently, research has been undertaken into the use of nanostructured powders, i.e. powders containing tungsten carbide particles of $<1 \mu \mathrm{m}$. Żórawski [3] performed a comparative analysis of a WC-12Co coating that was sprayed at high velocity using conventional powders and enabling obtaining

Corresponding Author: mgoral@prz.edu.pl a nanostructured coating. He showed that a nanostructured coating is $17 \%$ more hard. Myalska et al. [4] showed that the introduction of $\mathrm{TiC}$ nanoparticles into a conventional WC-17Co powder slows down the WC carbide decomposition process and improves tribological properties. Attempts are also being made to produce carbide coatings in the process of high velocity spraying from suspensions [5]. A lower resistance of WC-Co coatings sprayed from suspensions was found in comparison to coatings sprayed conventionally with the HVOF method. It was caused by, among others, the appearance of metallic tungsten due to the decomposition of WC carbide and the burning of carbon in the plasma stream during spraying. However, the results of corrosion tests presented in [6] indicate that nanostructured WC-Co coatings are characterised by better corrosion and erosion resistance. This was attributed, among others, to greater dispersion of finer carbide particles and greater adhesion of sprayed powder particles. The research conducted by 
Wang et al. [7] allowed the development of a mechanism of abrasion of nanostructured WC-Co coatings. Lima et al. [8] conducted a comparative analysis of nanostructured WC-Co coatings produced in the HVOF process as well as arc and flame spraying. It was found that the coatings, regardless of the method of thermal spraying, had similar thickness and hardness. The asperity of the coating sprayed during the HVOF process was twice lower - compared to the others.

Metaloceramic WC-Co coatings are used in aviation technology, e.g. to protect the surface of the compressor housing [9]. In the aerospace industry, metaloceramic coatings are most often plasma sprayed under atmospheric pressure, i.e. APS (Atmospheric Plasma Spray). This process is characterised by a higher stream temperature and lower speed - compared to the HVOF spraying process. The properties of the APS process determine the need to select thermal spraying parameters that ensure high particle kinetic energy and, consequently, low coating porosity. At the same time, it is necessary to limit the temperature of the sprayed particles due to the carbides' tendency to disperse in the plasma stream [10]. This is particularly important in the case of nanostructured coatings. The results of the research carried out by Bolleddu et al. [11] indicate that the size of the WC carbide grains does not significantly affect the phase composition of the coating sprayed at high velocity - compared to conventional WC-17Co powders. In the plasma spraying process, the dispersion of WC particles and the formation of pure tungsten were observed. Experimental processes of spraying conventional and nanostructured WC-Co powders in the APS process showed a significant effect of the chemical composition of plasma gases [12]. The introduction of helium into the plasma stream resulted in an increase in the hardness and strength of the carbide coating, among others due to the smaller degree of decomposition of the WC carbide with a lower energy of the plasma stream.

The analysis of literature data [9-12] indicates that the properties of metaloceramic coatings containing WC carbide with a particle size $<1 \mu \mathrm{m}$ depend on the choice of plasma spraying conditions. This requires experimental selection of spraying conditions for each type of plasma torch and powder. Hence, an attempt was made to select the conditions for the WC-CrNi powder spraying process using an A60 plasma torch. At the same time, it is necessary to determine the impact of the conditions of the spraying process not only on the microstructure and porosity of the coating, but also on other properties - hardness as well as erosion and corrosion resistance. The comparative analysis of test results was the basis for determining the conditions of the processes ensuring obtaining a nanostructured metaloceramic coating with the best possible properties.

\section{MATERIAL AND METHODOLOGY}

C15 non-alloy steel was assumed as the substrate material. Prior to the spraying process, the substrate was sanded and degreased with isopropanol. Thermico SJA 175 powder with the following composition was used to make the coating (wt \%): WC- $73 \%$, Cr-20\% and Ni-7\%. Plasma spraying at atmospheric pressure (APS) was performed using an A60 plasma torch (Thermico). The experimental processes included a change in the torch current, chemical composition of plasma gases and powder flow rate (Table 1). The feed speed of the torch was $50 \mathrm{~mm} / \mathrm{min}$, and the spraying distance $-100 \mathrm{~mm}$.
Table 1. Variable parameters of the spraying process Tabela 1. Parametry zmienne procesu natryskiwania

\begin{tabular}{|l|c|c|c|c|}
\hline Current, [A] & 300 & 450 & 600 \\
\hline \multirow{2}{*}{ Composition of plasma gases, $\left[\mathbf{d m}^{\mathbf{3}} / \mathbf{m i n}\right]$} & $\mathbf{A r}$ & 63 & 68 & 71 \\
\cline { 2 - 5 } & $\mathbf{H}_{\mathbf{2}}$ & 10 & 5 & 2 \\
\hline Powder flow rate, [g/min] & 10 & 20 & 30 \\
\hline
\end{tabular}

The microstructure examination was carried out using a Nikon Epiphot 300 light microscope coupled with a digital camera. Porosity measurement was made using the Aphelion 3.2 and NIS Elements 3.2 computer software. The powder morphology was examined using a Hitachi S-3400 scanning electron microscope. Vickers hardness measurement was made using an Innovatest Nexus 4303 microhardness tester. The erosion resistance test was carried out according to the ASTM G73 standard with a Koehler TR-470 device, at $25^{\circ} \mathrm{C}$ and $400^{\circ} \mathrm{C}$ for 10 minutes at an erodent flow rate (noble electro-corundum) of $2 \mathrm{~g} / \mathrm{min}$. The abrasive was striking perpendicular to the samples' surface.

\section{TEST RESULTS}

\subsection{MORPHOLOGY OF THE SPRAYING POWDER}

The microscopic examination of the Thermico SJA 175/080A powder showed that it consisted of single equiaxed particles and conglomerates formed as a result of melting of individual particles (Fig. 1). Based on the measurement of the size of selected particles during microscopic examination, it was found that their size is approx. 1.87 $\mu \mathrm{m}$, while in the case of conglomerates: $4.44-8.26 \mu \mathrm{m}$. The chemical composition analysis in the micro-area (Fig. 1a, b) showed the presence of $\mathrm{Cr}, \mathrm{Ni}$ - components of the metallic matrix, and $\mathrm{W}$ and $\mathrm{C}$ - components of tungsten carbide.

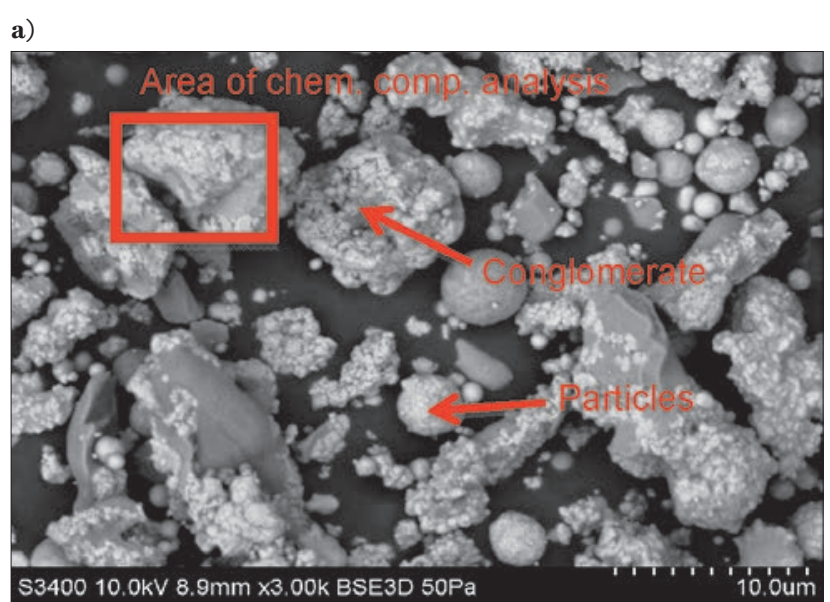

b)

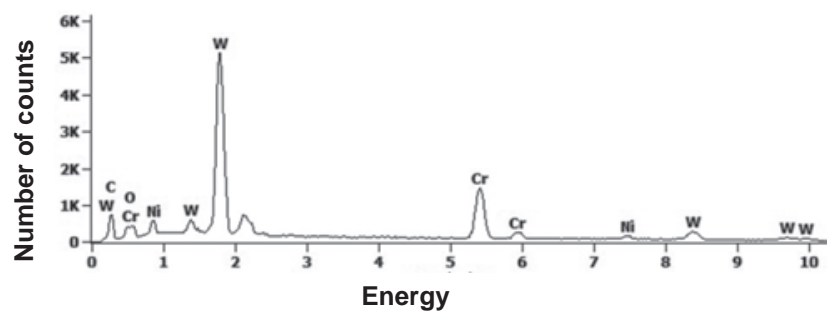

Fig. 1. Morphology of the SJA 175/080A powder grains (a) and the results of chemical composition microanalysis (b)

Rys. 1. Morfologia ziaren proszku SJA 175/080A (a) i wyniki mikroanalizy składu chemicznego $(b)$ 


\subsection{MICROSTRUCTURE AND POROSITY OF THE PRODUCED COATINGS}

Carbide coatings produced using the plasma spraying process, regardless of the process parameters, were characterised by a laminar structure. They are composed of molten powder particles and porosities typical of coatings sprayed using the APS method (Fig. 2).

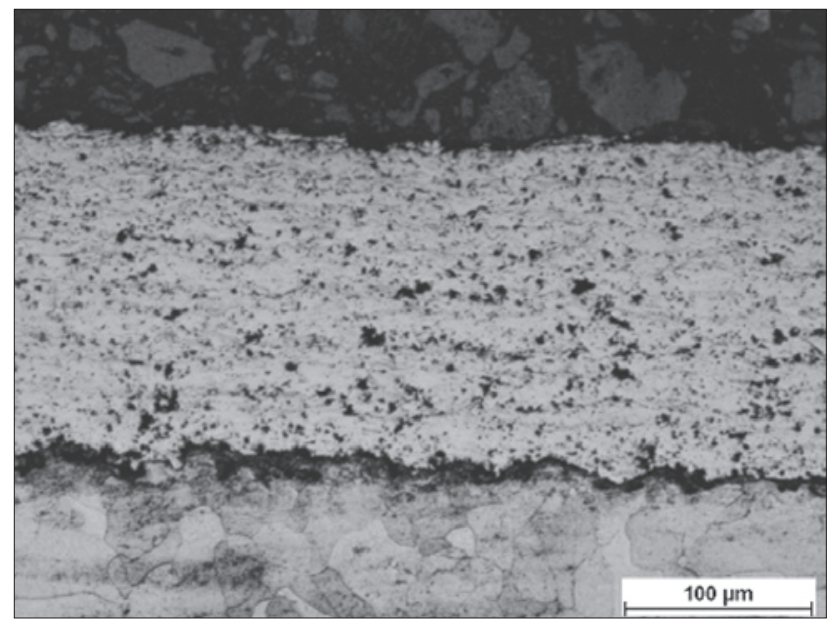

Fig. 2. Microstructure of carbide coating produced for the spraying parameters: torch current $I=450 \mathrm{~A}$, gas flow rate: $\mathrm{Ar}=68 \mathrm{dm}^{3} / \mathrm{min}$, $\mathrm{H}_{2}=5 \mathrm{dm}^{3} / \mathrm{min}$, powder flow rate $20 \mathrm{~g} / \mathrm{min}$

Rys. 2. Mikrostruktura powłoki węglikowej wytworzonej dla wartości parametrów natryskiwania: natężenie prądu palnika $I=450$ A, natężenie przepływu gazów: $\mathrm{Ar}=68 \mathrm{dm}^{3} / \mathrm{min}, \mathrm{H}_{2}=5 \mathrm{dm}^{3} / \mathrm{min}$, natężenie przepływu proszku $20 \mathrm{~g} / \mathrm{min}$

It was found that the torch's current intensity has little effect on the coating thickness. The thickness of the coating produced at the current $\mathrm{I}=450 \mathrm{~A}-176.74 \mu \mathrm{m}$ is the highest, and the lowest - the coating formed at the current $\mathrm{I}=300 \mathrm{~A}$ $-173.72 \mu \mathrm{m}$ (Fig. 3a). It was found that the torch's current intensity has little effect on the coating porosity. The lowest porosity $-4.88 \%$ is attributed to the coating produced at the current $\mathrm{I}=300 \mathrm{~A}$. The porosity of the coating sprayed at a current of $\mathrm{I}=450 \mathrm{~A}$ is $5.33 \%$ and at $600 \mathrm{~A}$ it is $6.28 \%$ (Fig. 3a).

The chemical composition of plasma gases affects the thickness and porosity of the produced carbide coatings (Fig. 3b). The hydrogen flow rate in the plasma stream of $10 \mathrm{dm}^{3} / \mathrm{min}$ (flow rate $\mathrm{Ar}=63 \mathrm{dm}^{3} / \mathrm{min}$ ) results in a decrease in thickness $(143.52 \mu \mathrm{m})$ and an increase in porosity (up to $6.65 \%$ ) of the coating (Fig. $3 \mathrm{~b}$ ). The reduction of

a)

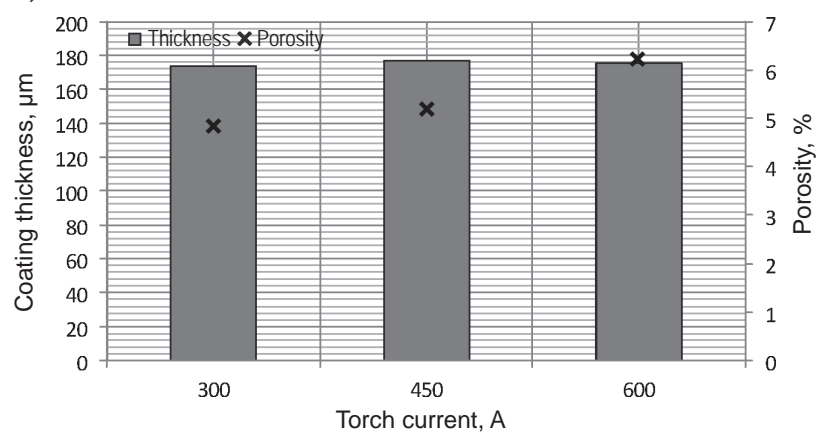

Fig. 3. Effect of torch current (a) on the thickness and porosity of carbide coating produced in the APS process

Rys. 3. Wpływ natężenia prądu palnika (a) na grubość i porowatość powłoki węglikowej wytwarzanej w procesie APS b)

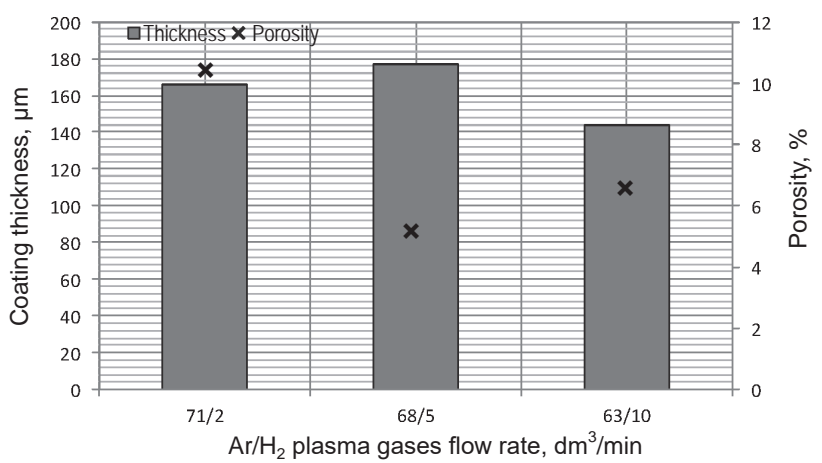

c)

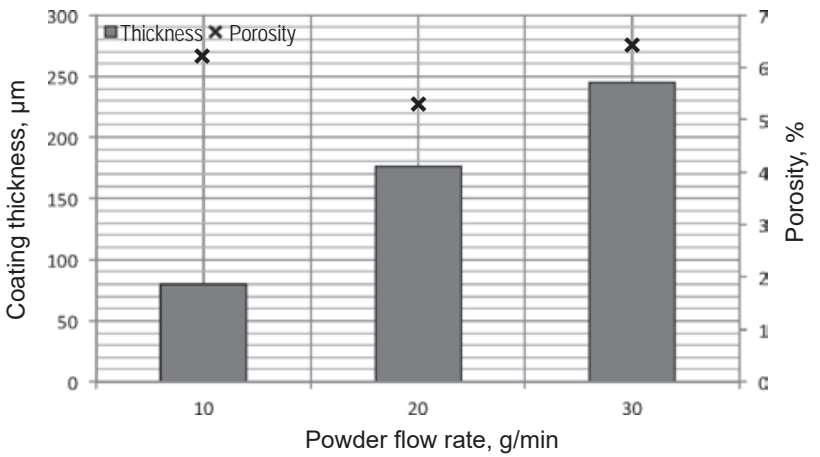

Fig. 3 cont. Effect of chemical composition of plasma gases (b) and powder flow (c) on the thickness and porosity of carbide coating produced in the APS process

Rys. 3 cd. Wpływ składu chemicznego gazów plazmotwórczych (b) i natężenia przepływu proszku (c) na grubość i porowatość powłoki węglikowej wytwarzanej w procesie APS

hydrogen flow rate to $2 \mathrm{dm}^{3}$ (flow rate $\mathrm{Ar}=71 \mathrm{dm}^{3}$ ) and, consequently, a decrease in the energy of the plasma stream causes a reduction in thickness to $165.73 \mu \mathrm{m}$ and an increase in the porosity of the coating - up to $10.48 \%$.

The powder flow rate has a great impact on the thickness and hardness of plasma sprayed coatings (Fig. 3c). It was found that at a powder flow rate of $10 \mathrm{~g} / \mathrm{min}$, the coating thickness was only $79.52 \mu \mathrm{m}$, and at a flow rate of $30 \mathrm{~g} / \mathrm{min}$ $-244.96 \mu \mathrm{m}$. Powder flow rate does not affect the porosity of the coating - it is on average about $5-6 \%$.

\subsection{HARDNESS AND EROSION RESISTANCE}

The highest hardness (758 HV0.5) is attributed to the coating sprayed at an intermediate value of current $\mathrm{I}=50 \mathrm{~A}$. An increase (up to $\mathrm{I}=600 \mathrm{~A}$ ) or a decrease (down to $\mathrm{I}=300 \mathrm{~A}$ ) of the current results in a decrease in hardness to $<640$ HVo.5 (Fig. 4a). This decrease is associated with changes in the energy of the plasma stream - a lower intensity limits the melting of metallic powder matrix $(\mathrm{Ni}$ and $\mathrm{Cr}$ ), and a larger - a partial distribution of WC carbide in the plasma stream. In the conducted research, however, no effect of hydrogen flow rate in the plasma stream on the hardness of the coatings was found - it was 730-760 HVo.5 (Fig. 4b). A significant impact of the powder flow rate on the hardness of the carbide coating was demonstrated. Reducing the powder flow rate to $10 \mathrm{~g} / \mathrm{min}$ causes a large decrease in the hardness of the coating - to 431 HVo.5 (Fig. 4c). It was also found that at a $30 \mathrm{~g} / \mathrm{min}$ powder flow rate, the hardness was only 515 HV0.5 compared to 758 HVo.5 for a coating produced at a powder flow rate of $20 \mathrm{~g} / \mathrm{min}$. 
a)

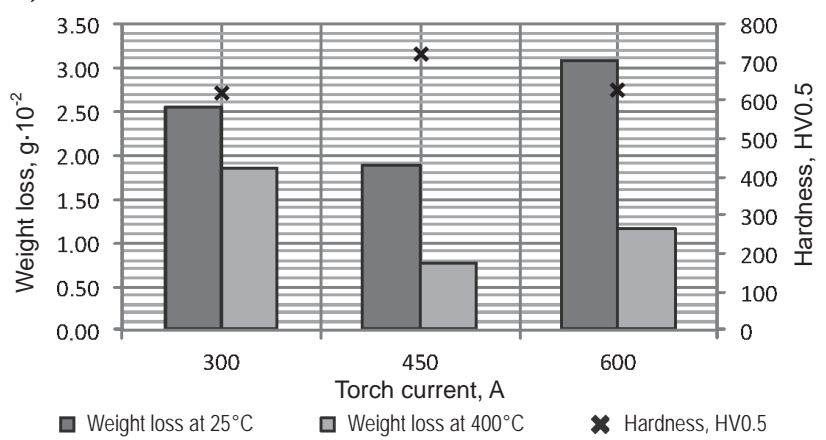

b)

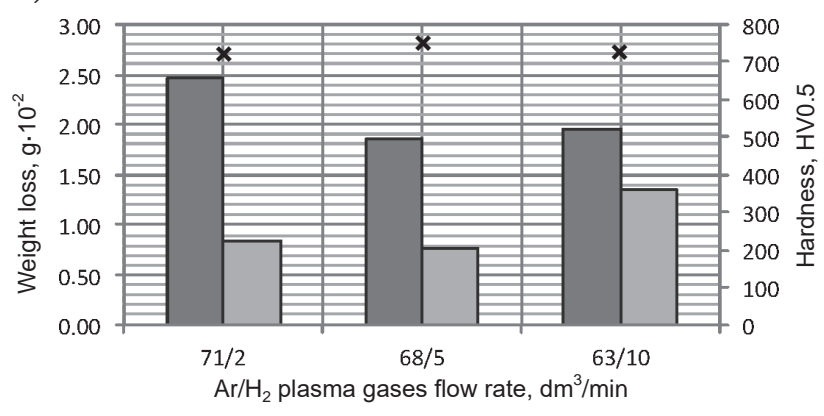

$\square$ Weight loss at $25^{\circ} \mathrm{C} \quad \square$ Weight loss at $400^{\circ} \mathrm{C} \quad \boldsymbol{x}$ Hardness, HV0.5

c)

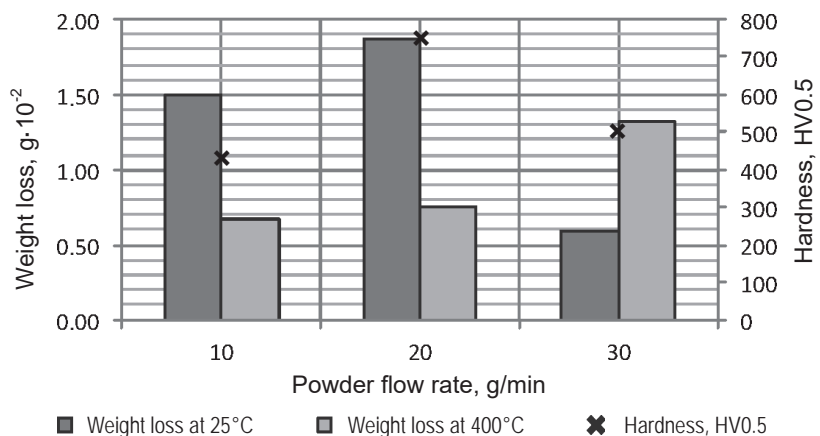

Fig. 4. Influence of torch current (a), composition of plasma gasses (b) and powder feed rate (c) on erosion resistance at room $\left(25^{\circ} \mathrm{C}\right)$ and increased temperature $\left(400^{\circ} \mathrm{C}\right)$ an the hardness of carbide coatings obtained in the APS process

Rys. 4. Wpływ natężenia prądu palnika (a), składu chemicznego gazów plazmotwórczych (b) i natężenia przepływu proszku (c) na odporność erozyjną w temperaturze pokojowej $\left(25^{\circ} \mathrm{C}\right)$ i podwyższonej $\left(400^{\circ} \mathrm{C}\right)$ oraz twardość powłoki węglikowej wytworzonej w procesie APS

Comparative tests of erosive resistance of the sprayed coatings were carried out both at room temperature $\left(25^{\circ} \mathrm{C}\right)$ and at elevated temperature $\left(400^{\circ} \mathrm{C}\right)$. It was found that regardless of spraying conditions, the erosion resistance of the coatings at elevated temperature is greater than at room temperature (Fig. 4a-c). This is probably due to a decrease in the hardness of the coating due to heat and a decrease in the hardness of the metallic matrix.

The value of the torch current while spraying the carbide coating affects its erosion resistance. It was found that the lowest weight loss is attributed to the sample with a spray coating at an intermediate value of torch current $\mathrm{I}=450 \mathrm{~A}$. Increasing or decreasing the current caused a greater weight loss of samples - lower erosion resistance of the coating (Fig. 4a).

The chemical composition of plasma gases also affects the erosion resistance of the carbide coating (Fig. 4b). At a high- er hydrogen flow rate -5 and $10 \mathrm{dm}^{3} / \mathrm{min}$ (Ar flow rate of 68 and $63 \mathrm{dm}^{3} / \mathrm{min}$, respectively) the weight loss of the samples during the erosion resistance test at $400^{\circ} \mathrm{C}$ is similar. At room temperature, the weight loss of the sample with the coating sprayed at high hydrogen flow rate $-10 \mathrm{dm}^{3} / \mathrm{min}$ is the largest. The carbide coating sprayed at the lowest hydrogen flow rate $\left(2 \mathrm{dm}^{3} / \mathrm{min}\right)$, and thus - the plasma stream energy, has the best erosion resistance at room temperature.

The conducted research revealed the impact of powder flow rate on the erosion resistance of the carbide coating (Fig. 4c). The largest weight loss during the erosion resistance test at room temperature was observed for the coating plasma-sprayed at a powder flow rate of $20 \mathrm{~g} / \mathrm{min}$. Increasing or decreasing the powder flow rate results in greater erosion resistance of the produced carbide coating.

\section{SUMMARY}

The results of the tests indicate a significant impact of the conditions of the spraying process on the microstructure and performance properties of the produced metaloceramic coatings. A fine-grained powder containing tungsten carbide was used in the conducted studies. Hence the need to perform experimental processes aimed at selecting the conditions to obtain the best possible properties of the sprayed coating. The obtained test results clearly show that the energy of the plasma stream determines the microstructure and erosion resistance of the metaloceramic coating, which is consistent with the literature data [12]. It was shown that the selection of current intensity $-450 \mathrm{~A}$ and flow rate $\mathrm{H}_{2}=5 \mathrm{dm}^{3} / \mathrm{min}$ (flow rate $\mathrm{Ar}=68 \mathrm{dm}^{3} / \mathrm{min}$ ), allows obtaining a coating with a thickness of approx. $177 \mu \mathrm{m}$ and low porosity $<6 \%$. At the same time, this coating is characterised by the greatest hardness -758 HV0.5, and the best erosion resistance at room and elevated temperature. A change in the torch current or hydrogen flow rate affects the energy of the plasma stream, and thus the properties of the sprayed coating. Lower current and hydrogen content in the plasma stream do not ensure sufficient melting of the metallic matrix of the powder - Ni and $\mathrm{Cr}$. This results in greater brittleness of the coating and lower erosion resistance. An increase in plasma stream energy due to an increase in torch current or hydrogen flow rate may cause tungsten carbide to decompose in the plasma stream - the phase affecting hardness and abrasion resistance [11]. The obtained results are consistent with the results of the study by Bonche et al. [10] in which it was shown that the intermediate energy value of the plasma stream ensures obtaining a WC-Co coating with the best erosion resistance.

The powder flow rate has a significant influence on the properties of the sprayed coating. A lower powder flow rate - $10 \mathrm{~g} / \mathrm{min}$ causes an increase in the degree of WC carbide dispersion and thus - a decrease in hardness and erosion resistance. Increasing the thickness of the sprayed coating at a higher powder flow rate $-30 \mathrm{~g} / \mathrm{min}$ increases its thickness, hardness and erosion resistance at room and elevated temperature $\left(400^{\circ} \mathrm{C}\right)$.

The comparative analysis of the obtained results of hardness measurement with literature data [12] also indicates that the coatings sprayed using the APS method are characterised by lower hardness compared to those sprayed at high velocity (HVOF) or low pressure plasma (LPPS). 


\section{REFERENCES}

[1] B. Formanek, K. Szymański, B. Szczucka-Lasota, A. Włodarczyk. New generation of protective coatings intended for the power industry. Journal of Materials Processing Technology, 2005, 164-165, p. 850-855.

[2] H. Myalska, J.K. Michalska, G. Moskal, K. Szymański. Effect of nano-sized TiC powder on microstructure and the corrosion resistance of WC-Co thermal spray coatings. Surface and Coatings Technology, 2017, 318, p. 270-278.

[3] W. Żórawski. Właściwości nanostrukturalnych powłok węglikowych natryskanych naddźwiękowo. Tribologia, 2010 (6), p. 307-316.

[4] H. Myalska, L. Lusvarghi, G. Bolelli, P. Sassatelli, G. Moskal. Tribological behaviour of WC-Co HVAF-sprayed composite coatings modified by nanosized TiC addition. Surface \& Coatings Technology (2019), 371, p. 401-416.

[5] R. Ahmed, G. Vourlias, A. Algoburi et al. Comparative study of corrosion performance of HVOF-sprayed coatings produced using conentional ans suspension WC-Co feedstock. Journal of Thermal Spray Technology 2018, 27 (8), p. 1579-1593.

[6] A. Lekatou, D. Sioulas, A.E. Karantzalis, Grimanelis D. A comparative study on the microstructure and surface property evaluation of coatings produced from nanostructured and conventional WC-Co powders HVOF-sprayed on AI7075. Surface \& Coatings Technology, 2015, 276, p. 539-556.
[7] H. Wang, C. Hou, Xuemei Liu, Xingwei Liu, X. Song. Werar resistance mechanisms of near-nanostructured WC-Co coatings. International Journal of Refractory Metals \& Hard Materials, 2018, 71, p. 122-128.

[8] C.R.C. Lima, R. Libardi, F. Camargo, H.C. Fals, V.A. Ferraesi. Assesment of abrasive wear of nanostructured WC-Co and $\mathrm{Fe}$ based coatings applied by HP-HVOF, flame and wire arc spray. Journal of Thermal Spray Technology, 2014, 23 (7), p. 1097-1104.

[9] T.N. Rhys-Jones. The use of thermally sprayed coatings for compressor and turbine applications in aero engines. Surface and Coatings Technology, 1990, 42 (1), p. 1-11.

[10]V. Bonache, D.M. Salvador, J.C. Garcia, E. Sanchez, E. Bannier. Influence of Plasma Intensity on Wear and Erosion Resistance of Conventional and Nanometric WC-Co Coatings Deposited by APS. Journal of Thermal Spray Technology, 2011, 20 (3), p. 549-559.

[11] V. Bolleddu, V. Racheria, P.P. Bandyopadhyay. Comparative study of air plasma sprayed and high velocity oxy-fuel sprayed nanostructured WC-17wt\%Co coatings. International Journal of Advanced Manufacturing Technology, 2016, 84, p. 1601-1613.

[12] L.M. Berger, S. Saaro, T. Naumann, M. Kasprowa, F. Zahalka. Influence of feedstock powder characteristics and spray processes on microstructure and properties of WC $-(\mathrm{W}, \mathrm{Cr}) 2 \mathrm{C}-\mathrm{Ni}$ hardmetal coatings. Surface \& Coatings Technology, 2010, 205 (4), p. 10801087. 